\title{
Saturnine Texts and Parodic Sunrises: Don Quixote and Le Roman Comique
}

\author{
Frederick A. de $\operatorname{Armas}^{1}$ (D)
}

Accepted: 27 November 2020 / Published online: 3 January 2021

(C) The Author(s) 2021

\begin{abstract}
This essay analyzes Scarron's careful imitation of Cervantes' Don Quixote, and how many of the traits are transformed into a less complex novel. In order to comprehend this shift, the essay will look at three key elements in the two novels. While Cervantes fashions himself as a saturnine author, Scarron fails to fully self-fashion. Secondly, this piece will focus on the solar image used at the beginning of the two novels; and third we will consider the construction of the main character in these works. While both novels shadow the solar author and protagonist, Cervantes makes them into melancholy figures that conceal wisdom. Scarron, on the other hand, exhibits a noisy author/narrator that cannot abide saturnine sufferings and utilizes clatter and chaos to rail against the heavens. He is unable to turn his idealized main character (Destiny) into someone that can both be part and rise above the noise of the world.
\end{abstract}

Keywords Don quixote $\cdot$ Roman comique - Cervantes · Scarron · Dawn images · Saturn $\cdot$ Sound $\cdot$ Parnassus $\cdot$ Parody $\cdot$ Shadow $\cdot$ Disabilities

Cervantes' Don Quixote has the distinction of being one of the most translated books in history, "rendered into some fifty languages" (Stavans 2015: 172). Indeed, "other than the Bible no other book has been translated into Shakespeare's tongue as often" (Stavans 2015: 176-77). Its success was gradual, first considered a comic work, its main figures featured in festivals and carnivals of the period, and even in an early seventeenth-century engraving that "shows seven rather grotesque figures dressed in exaggerated, festive, carnival costumes and appearing in procession" (Lo Ré 1990: 96). However, it was canonized in the eighteenth century as a satire and as a work akin to epic. Its initial success prompted a series of imitations, ${ }^{1}$ one of

\footnotetext{
1 Charles Sorel penned the first two French imitations. The first one was the Francion (1623) and soon thereafter Le Berger extravagant (1627-28) which restricted its parody to the pastoral romances. Daniel Syrovy points out that already in the seventeenth century it was seen as a parody of the novels of the

Frederick A. de Armas

fdearmas@uchicago.edu

1 Department of Romance Languages and Literatures, University of Chicago, 115 E. 58th Street, Chicago, IL 60637, USA
} 
the most thorough and successful being Paul Scarron's Roman comique, with a first part published in 1651 almost 50 years after the publication of Don Quixote. Scarron delighted in different modes of parody, and particularly travesty, ${ }^{2}$ and his novel became an instant, albeit controversial success.

In contrast to the ever-growing appreciation of Cervantes' novel, Scarron's novel faded away over time. While it was a polemical success in the seventeenth century, critics prefer to point to Madame de La Fayette's La princesse de Clèves as the starting point for the French novel; and while it was the subject of two continuations, its resonance waned over the centuries. ${ }^{3}$ Voltaire dismissed Scarron as a burlesque writer, a trait which lessened his dignity. ${ }^{4}$ This attitude continues even today as Scarron's novel is seldom read: "According to a very informal poll, it would seem that only professors of French whose field of interest is the seventeenth century have read Le Roman comique" (Ekstein 1988: 41 note 1). Over the centuries, there have been a couple of exceptions to this disregard for Scarron. Peter V. Conroy asserts: "Critics today recognize one merit in Scarron's novel: its influence upon the precociously modern Diderot" (Conroy 1974: 18), one that has to do with the continuous interruptions of his narrator which point to "his active presence in the novel" (1974: 18). ${ }^{5}$ In addition, Théophile Gautier's Capitaine Fracasse (1863) takes the plot of Scarron's novel and makes it into a romantic tale of a ruined aristocrat in love

\section{Footnote 1 (continued)}

period, of which Don Quixote was the first. Syrovy cites in this respect Gesprächspiele by polymath Georg Philipp Harsdörffer (1607-1658) (2013: 9-15). Syrovy explains: “... he appears thoroughly convinced that the purpose of both writers was first and foremost the ridicule of worthless fiction. Curiously, while Cervantes has the obvious advantage of having come first, thus serving as a specific model for the overall design, Sorel is-almost in passing-called the better writer of the two" (Syrovy 2013: 14).

${ }^{2}$ His Typhon (1644) is a travesty of the genre of the gigantomachia, where a high matter is treated in a low style. It begins as the giants play a game of ninepins, but with immense rocks. As one of them hits Typhon, he takes all his rocks and hurls them in anger with such force that they hit Olympus. It is thus that they start a war with the gods. Similarly, his Virgile Travesti mocks the Aeneid by demeaning the characters in the epic.

3 While Cervantes would publish his second part in 1615, Scarron would bring to light his continuation in 1657. Unlike Cervantes, who ends his work with the death of the knight, Scarron leaves his work unfinished. He was completing a third part at the time of his demise, and its publication seemed imminent in 1660, since he had taken out a privilege for publication. Thus, continuations to his work followed after his death, while Cervantes had to deal with a "false" Quixote published in 1614. The "Offray" continuation appeared in 1663 in Lyons. But the name refers to the publisher, while the work remains anonymous. Henri Chardon attributes it to Jean Girault (Chardon 1904: 286-366) but not all agree. This continuation attempts to tie all the threads of the narrative and solve the mysteries. As expected, Angelique marries Léandre while Destin marries Estoile. However, many of the mysteries of this plot are not solved (De Armas 1972: 94-5). Another continuation by Jean de Préchac was published in 1679. Its idealizing qualities are much more prevalent than in the original and in the first continuation. In addition, he does not conclude the work but takes it to a moment of crisis. He never published the fourth part.

4 See his anecdotes on the reign of Louis XIV.

5 Conroy adds that: "His particular tone of voice, his intrusions and interruptions, everything that constitutes his role as narrator, are all carefully limited to the main plot line. He disappears completely from the inserted stories" (1974: 19). Conroy does admit that in the first tale, the narrator carefully explains that it is not told in Ragotin's words but is transformed by the narrator-and this narrator is as intrusive as in the main plot. However, this intrusiveness, although to a much lesser extent, also appears in some of the other interpolated tales (See De Armas 1972: 76-81). 
with Isabelle, lead actor in a troupe of players. ${ }^{6}$ Some of Scarron's critics debate the intrusiveness or relevance of the four interpolated Spanish tales within the novel ${ }^{7}$; while others still consider it mainly as one in a series of French anti-novels that originated with Rabelais. ${ }^{8}$ Some even reject its status as a realistic novel ${ }^{9}$; while others complain of the "apologetic and justificatory" tone of critical approaches (Ekstein 1988: 33). ${ }^{10}$ Even with the rise of studies on persons with disabilities, Scarron has remained at the margins. ${ }^{11}$ This article includes the uses of disabilities in Cervantes and its impact on Scarron, ${ }^{12}$ but focuses on Scarron's inventive and heuristic imitation of Cervantes. ${ }^{13}$ First, I will discuss a section of the paratext, the threshold or vestibule of the novels, seeking to apprehend how the authors represent themselves

\footnotetext{
${ }^{6}$ Gautier admired the non-canonical writers of the seventeenth century, and thus he praised them in his essays on the Grotesques. The Capitaine Fracasse tempers the excessive slapstick humor of the Roman comique and elevates the action, now filled with adventures: "Ainsi s'ouvre un univers d'où s'élimine la seule laideur vraie, celle de la bassesse d'âme et de la banalité... Sur la route de l'aventure, le Capitaine Fracasse cherchait l'idéal" (Jasinski 1948: 156).

7 Critics have many differing viewpoints on the interpolated tales. Cadorel claims there are no links between the tales and the main plot (Cadorel 1960); Ernest Simon provides a detailed analysis of the first interpolation and its relationship to the rest of the novel (1963: 130-37); while Frederick A. de Armas discusses all four interpolated tale and its links to the novel: while the first two echo love situations in the main plot; the last two are concerned with justice (1972: 81-92).
}

8 These include works by Rabelais, Sorel, Scarron, Marivaux and Voltaire (Hogdson 1982: 340-48). Antoine Adam, in his introduction to the novel, asserts the opposite: "Mais non pas anti-roman comme l'avait été le Berger extravagant, ou comme le sera le Roman bourgeois" (1958: 38).

9 In the introduction to the novel, Antoine Adam asserts: "Ne disons même pas roman réaliste, car Scarron n'a point dessein de nous donner un tableau d'une exactitude prudente en minutieuse" (1958: 38). At the same time, Adam compares Scarron to the Dutch painter "le Bamboche" who delights in representing a reality that "se charge de truculente trivialité et s'agite en gesticulations désordonnées et pittoresques" (1958: 40).

10 There are some important studies that seek to "order" and add meaning to what seem a rather chaotic narrative. Joan DeJean seeks order in the narrator's interventions (1977: 30); while Jean Serroy proposes a structure based on characters that chase each other (1981: 472).

11 Lennard J. Davis gives a brief catalogue of authors with disabilities: "Rosa Luxemburg (who limped), Antonio Gramsci (a crippled, dwarfed hunchback), John Milton (blind), Harriet Martineau (deaf), Alexander Pope (dwarfed hunchback), George Gordon Byron (club foot), Jorge Luis Borges, James Joyce, James Thurber (all blind), Toulouse-Lautrec (spinal deformity), Frida Kahlo (ostiomyelitis),Virginia Wolf (lupus)" (1995: 6). Howard Margolis and Arthur Shapiro have discussed the negative view of characters with disabilities in literature: "The sinister hump of Richard III, the evil prosthesis of Captain Hook, the fear inducing, thumping wooden leg of Captain Ahaband the pitiable crutch of Tiny Tim are all allegorical symbols in our culture" (1987: 18).

12 On Cervantes and disabilities see, for example, Elizabeth E. Bearden. Studying the Persiles in terms of the Byzantine novel, she concludes: "Cervantes was physically impaired and made this impairment a part of his authorial identity. Noting how this impairment was disabling, and examining the way he represents his impairment contributes to disability studies in several ways. From a New Historical perspective, it helps add to our archive of disability representation. It contributes to our understanding of biographical criticism of disability and adds social realism to the depiction of disability in the past. Finally, and most importantly for my concept of crip authority, Cervantes provides us with a transgressive reappropriation of disability in a time period that most disability scholars have not recognized to be capable of such statements" (Bearden 2016: 81).

13 Thomas Greene explains that heuristic imitations: "Come to us advertising their derivation from the subtexts they carry with them, but having done that, they proceed to distance themselves from the subtexts and force us to recognize the poetic distance traversed" (1982: 40). While Scarron departs from idealized fiction through constant parody, his imitation of Cervantes is particularly inventive. 
through humoral theory and how they characterize their work. ${ }^{14}$ Secondly I will turn to the beginnings of the text, the chapters that ease the readers into the fiction, and describe contrast its solar images, be it of dawn or dusk, showing how Scarron veers away from Cervantes. Turning to the main characters I will argue that Don Quixote and Sancho, cannot be equated with Destin and Ragotin. Scarron, as will be explained, is unable to make them into fully fleshed-out characters, keeping human agony away from them. Throughout, I will keep in mind parody as a way to foreground a realist fiction over the idealist. While Cervantes parodies the romances of chivalry, Scarron, while continuing this method, prefers to parody the heroic novels of Gomberville, La Calprenède and Georges and Madeleine de Sudery. ${ }^{15}$

The Prologue to Don Quixote, albeit a parody on the authority of the written word, ${ }^{16}$ is much more a portrait of an artist and an example of literary criticism directed at Cervantes' own work. Here, he fashions himself as an artist who is separate from the canon of his day. The Prologue begins is a manner not so different from other works since it makes use of the humility topos, but transforms it in unexpected ways. The fictive author claims that he would have liked to have given birth to a book / child of great beauty and genius. But instead, he is gifting the reader "un hijo seco, avellanado, antojadizo y lleno de pensamientos varios y nunca imaginados" (2007: 7). This is the result of the book's birth in a prison full of gloomy sounds ("triste ruido") rather than in a site amenable to writing. The fictive author thus contrasts this genesis with more accomplished texts born in places akin to Parnassus where the muses can easily be of assistance. It has been argued that Cervantes' description is actually an ekphrasis of Raphael's fresco on the subject at the Vatican (De Armas 2006 34-35). It also recalls the many texts that invoke Apollo and Parnassus in their desire for canonicity. ${ }^{17}$ The Prologue, then, constructs an author who is far from Apollo and his Muses, and who is confined to a prison in which his book is born.

I would argue that this darker place, far from Parnassus is the habitation of the children of Saturn, those meant to suffer the planet's perils. As far back as Ptolemy and well into the Renaissance, Saturn was considered the most malefic of planets. Those

\footnotetext{
14 "More than a boundary or a sealed border, the paratext is, rather, a threshold, or-a word Borges used apropos of a preface-a "vestibule" that offers the world at large the possibility of either stepping inside or turning back" (Genette 1997: 1-2).

15 As if to nod to Cervantes, Scarron also includes not one, but two interpolated tales in the first part of his novel in imitation of El curioso impertinente. The second part of the novel will exhibit two additional interpolated tales: "Le juge de sa propre cause" (chapter 14) borrowed from María de Zayas and "Les deux frères rivaux" (chapter 19) taken from Castillo Solórzano.

16 On questions of authority in the prologue see Carolyn Nadeau for whom the Prologue serves as format: "for Cervantes' critical position on transmitting literary and, by extension, cultural authority.... Cervantes undermines the idea of 'sources' as authority" (2002: 38). Daniel Lorca explains that the Prologue reflects skepticism since 'the rejection of authority... is used to construct the greater part of the prologue by mocking authority" (2010: 119).

17 Quevedo's El Parnaso español (1648) brings together hundreds of his poems under the tutelage of the muses. His Las Tres Musas Últimas Castellanas (1670) was published long after his death with the three remaining Muses: Euterpe as muse of amorous poetry, Caliope of satiric poetry and Urania of religious verse. For the many images of Parnassus see Vélez (2006).
} 
under him could suffer many misfortunes, incarceration being one of its most prevalent. In his important compendium on the ancient gods, Baltasar de Vitoria asserts: "Es su condición maligna... Significa cárceles, prisiones, caminos largos, trabajos, tardanzas $y$ aflicciones" (1676: 22). ${ }^{18}$ The authorial figure of the Prologue is placing himself under Saturn, pointing to incarceration as the genesis of his book, but perhaps also inviting the reader to recall all the travails Cervantes endured in his life, his many toils, the slowness and shadowy nature of his career, where success is but a mirage until age fifty-seven when he published Don Quixote. This new book, born under Saturn, cannot be the beautiful product of the Muses. Instead it is dry and whimsical. Saturn as the farthest of all Ptolemaic planets from earth is cold and dry. ${ }^{19}$ Its influence could not be further from the solar-Apollonian warmth and vitality which allowed for the beauties of Parnassus. Cervantes shows himself shadowed, away from the light of canonicity, suffering from the delays of Saturn. Nevertheless, all of this serves Cervantes well. It not only explains his late arrival in the literary scene, but it also gives his work an aura of uniqueness, as he dons the mantel of a more obscure but revered tradition.

In order to emphasize his status he includes a self-portrait: "Muchas veces tomé la pluma para escribille, y muchas veces la dejé, por no saber lo que escribiría; y estando una suspenso, con el papel delante, la pluma en la oreja, el codo en el bufete y la mano en la mejilla, pensando lo que diría..." (Cervantes 2007: 8). The text draws upon the traditional pose of the thinker, most often considered as a melancholy figure. And again it shows delays, as he seems unable to write. However, as Raymond Klibansky, Erwin Panofsky and Fritz Saxl have explained, saturnine melancholy is not just a negative quality. Over time, melancholy became associated with creative genius (Klibansky et al. 1964: 254-399). By the time Cervantes writes his novel portraying himself in the melancholy pose of a Michelangelo (De Armas 2006: 75), the planet Saturn and its melancholy qualities have been re-envisioned in this manner. Marsilio Ficino, Renaissance philosopher and translator of Plato, in his Three Books on Life affirms that the child of Saturn is: "an individual set apart from others, divine or brutish, blessed or bowed down with the extreme of misery" (Ficino 1989: 251). While Cervantes first turns to the shadowed and negative aspects of Saturn and melancholy, he uses the bipolar nature of the humor and planet to hint at a reversal. As the Cervantes figure sits in a melancholy pose, he can be regarded as a symbol of the new artist or writer who suffered Saturn's melancholy in order to receive its most precious gift, wisdom, which was to be wrenched out of madness, one of the planet's worst effects. ${ }^{20}$

\footnotetext{
18 Vitoria discusses the twenty most important gods of the ancients in his book, twelve gods and eight goddesses. Acknowledging the importance of Saturn, he begins his book with this god. He also begins in this manner because "muchos tuvieron a este por padre de todos los Dioses" (1676: 3).

19 "su calidad es destemplada en frialdad y sequedad" (Vitoria 1676: 22).

20 Indeed, it has been claimed that: "from the sixteenth century onwards, there are frequent references to the melancholic disposition of artists in relation to their exceptional talents" (Van den Doel 2010: 108). Javier Portús prefers to take this image of the melancholy artist (and poet) back to the fifteenth century: "A partir del siglo XV se produjo un intenso proceso de... reivindicación de la aportación específica del individuo en los procesos culturales. Como consecuencia de todo ello, se enriqueció notablemente la casuística relacionada con la caracterología del poeta, el pintor, etc., a los que se asignaban una serie
} 
As someone outside the literary centers of his time, Cervantes consciously designs a new persona for himself. Not invited to Apollo's Parnassus, he designs a solitary figure that writes under Saturn, the highest of planets and the one that provides whimsical visions that shadow great wisdom. ${ }^{21}$

Paul Scarron, very much like Cervantes and other writers of the period, includes in his paratexts the humility topos. In a dedicatory, he stresses the worth of his recipient more than that of the book: "Il fera passer mon livre pour bon, quelque méchant qu'il puisse estre; et ceux mesmes qui trouveront que je le pouvois mieux faire, seront constraints d'avouer que je ne le pouvois mieux dédier" (Scarron 1958: 531). He then hints at an ailment that he contracted in 1638 and that would over time cause deformities and pain. His body became twisted and his legs paralyzed: In other words, since his illness impedes his motion and the full use of his faculties, he will delight his patron with his utterances. "Je serais assez récompensé de mon livre si vous daignez seulement le recevoir et si vous croyez sur ma parole, puis-que c'est tout ce qui me reste" (Scarron 1958: 531). Scarron whishes that his patron accept his word; but his word, as well as the words of the text emerge from a writer who is in pain, and may not sound as they would otherwise. Nika Ekstein has argued that Scarron's novel is full of noise. Indeed, she claims that it is the noisiest work she knows (1988: 33). I would also add that Scarron re-imagined this noise from Cervantes' prologue where he tells how he wrote his novel in a jail filled with gloomy sounds (triste ruido). For Scarron, this noise becomes the chaotic and rambling sounds of a body in pain, of a mind incarcerated in an ever more constricted and twisted frame. In the Roman comique, Scarron transforms the noises, akin to those Cervantes hears in the jail, into misaligned and capricious plots, jarring scenes and slapstick comedy.

In a warning to the reader, Scarron provides a clearer hint of how he wishes to characterize his work. A title in bold calls on "AU LECTEUR SCANDALISÉ", while in smaller type under it, he explains: "Des fautes d'impression qui sont dans mon livre" (Scarron 1857). ${ }^{22}$ It is as if scandal and error are keys to the book. This may be done on purpose, given the scandal caused by his style among the more classical-minded at the court. While Cervantes, as a saturnine writer, hopes to reach heights greater than Parnassus, Scarron rejects the lofty, pointing to his voice, the Cervantine noise of the jail transformed into a body, the errors of his book that perhaps echo the "errors" of his body. The noise, errors and scandals he creates serve to undermine the writers of Parnassus. After all, his poem Typhon begins by describing monstrous giants who, while playing, and by mistake, attack the lofty abodes of the gods.

Footnote 20 (continued)

de características relacionadas con sus temperamentos, humores, o con los rasgos de su personalidad" (Portús 2008: 136).

21 The dedicatory to the Duke of Béjar, albeit taken from one by Fernando de Herrera, also sees to include the notion of shadow, that is, of Saturn as a shadowed planet in opposition to the sun: "para que a su sombra, aunque desnudode aquel precioso ornamento de elegancia y erudición..." (2007: 6).

22 This section of the paratext is not included in Antoine Adam's 1958 edition. I have taken it from the online version of Fournier's 1857 edition. It also appears in a recent English translation (2012: 4). 
Having discussed the preliminaries of the two works, it is time to turn to how each writer begins his novel. Cervantes uses a double beginning. In the second chapter, Don Quixote imagines how the chronicler or sage would begin the tale of the knight's deeds: "Apenas había el rubicundo Apolo tendido por la faz de la ancha y espaciosa tierra las doradas hebras de sus hermosos cabellos, y apenas los pequeños y pintados pajarillos con sus harpadas lenguas habían saludado con dulce y meliflua armonía la venida de la rosada aurora, que, dejando la blanda cama del celoso marido, por las puertas y balcones del manchego horizonte a los mortales se mostraba, cuando el famoso caballero don Quijote de la Mancha... (2007: 35).

The passage sets up a clever contrast between the real and the ideal: a feeble older gentleman going out into the fields of a little-known area of the Spanish peninsula with a rusted armor and riding and old nag; and a majestic sunrise, symbolic of a solar hero, composed in a high style reminiscent of dawn descriptions that evoke the notion of perpetual springtime as realized during the Golden Age of humankind. Perhaps the knight hopes that this solar light will transform his sickly yellowish complexion into the shining youthfulness of the god. ${ }^{23}$ In fact, he dares to call the beginning of his first sally a "happy time" since it will bring about a mythical time. In so doing, there might be here an implicit comparison with the Spanish Habsburg emperors, who, under Apollo's mantle, were called to bring back a Golden Age to the empire (De Armas 2006: 127).

This attempt at authorship on the part of the knight is humorous since the hyperbole of the description contrasts with the narrator's statement that he was traveling through rustic fields, lacking poetic significance (Allen 1969: 61). As Francisco Rico states in his edition: "lo significativo está sobre todo en el contraste entre la grandilocuencia del lenguaje y la imagen grotesca de don Quijote y Rocinante en el áspero paisaje manchego" (2007: 35 note 19). Don Quixote is far from the handsome god of light who rises and falls every day; and Rocinante is nothing like the majestic steeds that Phoebus firmly controls in the journey through the skies. It is also hard to picture the rosy Aurora who rises from her couch, a commonplace in the poetry of the period, somehow waking in the rural and forgotten La Mancha. ${ }^{24}$ The passage may echo the epic style of the ancients, as John J. Allen has argued (1969: 58-63). ${ }^{25}$ It could also borrow from a chivalric romance that Cervantes often cited,

\footnotetext{
${ }^{23}$ Comparing this initial sally with Titian's painting of Charles V at Muhlberg, Frederick de Armas states: "Apollo then became a god of empire and more particularly of the pax romana brought about by Augustus, a peace equated with the mythical Golden Age. These associations were not lost in the Habsburg image-makers.... Apollo's golden locks, his solar light, is thus as important to the initial portrait of Don Quixote as it is to Titian's portrayal of a solar emperor" (2006: 127).

24 José María Paz Gago argues: "pues la rosada Aurora-otro tópico muy frecuentado en la época, por ejemplo, por Garcilaso: en mostrando el aurora sus mejillas de rosa-viene por las puertas y balcones del manchego horizonte, referencia a la árida topografía real pero poco propicia al retoricismo poético" (Paz Gago 1995: 139).

25 John J. Allen analyzes the six main dawn descriptions in the novel, and finds that three derive from lyric and three from epic. This division is based on Riley's study of examples taken from Alonso López Pinciano's Philosophía Antigua poética (Riley 1956: 125-37). This first example, Allen claims, is the only one where we can laugh at Don Quixote's expense. The humor arises from "the outrageous hyperbole" (1969: 61).
} 
Belianís de Grecia; or even from the lesser-known Historia del invencible cavallero don Polindo, as William Worden has recently argued (Worden 2019: 26-28). It can even recall dawn descriptions in Cervantes' own novel La Galatea. In reality, it incorporates and encompasses many such passages that evoke the dawn. ${ }^{26}$ The words by Don Quixote call to mind two approaches to writing: idealist fiction, which the knight envisions as pertaining to his quest, and realist depictions as presented by the narrators of the work. ${ }^{27}$ Cervantes thus incorporates in one novel at least two main ways of telling. This is a complex and multifaceted entry into the gates of storytelling, one which resembles what Simon Dentith (2000) defines as the ability of parody to bring out a double voice, with "the paradoxical effect of preserving the very text that it seeks to destroy" (Dentith 2000: 36). Cervantes' novel actually goes one-step further. While it may preserve the old idealist fiction (the canon of Toledo in the novel is writing his own chivalric book) ${ }^{28}$ it also renews that which it seeks to destroy by giving Don Quixote his own voice. ${ }^{29}$ As an artist, the knight paints over the world as he engages in his own adventures where inns are castles and windmills are giants. This divergence allows us to laugh and sympathize at the same time. Eventually, if we share in the "romantic approach" to the novel, ${ }^{30}$ we come to appreciate the knight's tenacity, his determination, his ability to move forward in the midst of adversity. His words, his vision, clash with those of the different narrators.

Indeed, these narrators would commence his story in a very different manner: "En un lugar de La Mancha, de cuyo nombre no quiero acordarme, no ha mucho tiempo que vivía un hidalgo... (2007:27). Rather than beginning with the evocation of a great kingdom, the "realist" narrator chooses a little-known and rustic area of Spain, and even leaves out the name of the town. As for the gentleman, he is around 50 years old and impoverished. Indeed, he has no clear name or lineage as the author provides different possibilities: Quixada, Quesana, Quixana. He is not of royal blood or of the high nobility and neither is he ready for great combat. As Juan Bautista Avalle-Arce has stated, the work parodies the chivalric romances such as the Amadís de Gaula since the "true" chivalric hero is a nativitate determined to do great deeds (Avalle-Arce 2002: n.p.). Since there is no pre-history in Cervantes,

\footnotetext{
${ }^{26}$ For dawn passages in the poetry of the period see María Rosa Lida de Malkiel (1964: 77-110).

27 In the nineteenth century, the realist approach to fiction was defined by Edmond Duranty as: "representing the social side of man, which is his most visible, the most accessible and most varied side, and to cling likewise to the idea of reproducing the things which affect the life of the greatest number, which occur frequently in the realm of the instincts, desires and passions... demanding from the artist useful truth" (Travers 2001: 102).

${ }^{28}$ Let us not forget that in chapter 48, the canon who accompanies the knight back to his home, although criticizing chivalry admits that "I myself... was once tempted to write a book of knight errantry, in which I proposed to observe all the restrictions I have mentioned, and, to confess the truth, I have gone through a hundred sheets of it" (1998: 427).

${ }^{29}$ Curiously, in the second part of the novel, Cide Hamete Benengeli, the Moorish "historian" who is said to have composed the novel, seems influenced by Don Quixote as he provides a dawn description at a time when Sancho and the squire of the Knight of the Mirrors converse.

30 For Anthony Close (1978) the romantic approach includes the idealization of the hero and of his lady. This approach became possible through "ways of looking at literature which presuppose that its meaning lies below the ostensible surface-i.e., various forms of symbolical criticism (1979: 3).
} 
there is no determinism. This determinism is found in the picaresque to retain the protagonist in the lower classes. Here, Don Quixote is a poor hidalgo, comparable to a forgettable bourgeois. To further the parody on the romances, we witness a gentleman who not only is too old to begin a chivalric quest, but he does so at the wrong time of the year, in the month of July when armor is bound to overheat him as he rides. Much more can be adduced concerning this initial parody, but what is significant is the creation of an eccentric character who wishes to break the boundaries of his existence by imagining himself a knight of old. These two ways of telling will continue to clash throughout the novel.

Scarron, well-aware of Cervantes' beginnings, chooses to start his novel with a solar image: "Le soleil avoit achevé plus de la moitié de sa course et son char, ayant attrapé le penchent du monde, roulloit plus viste qu'il ne vouloit. Si ses chevaux eussent voulu profiter de la pente du chemin, ils eussent achevé ce qui restoit du jour en moins d'un demy-quart d'heure: Mais, au lieu de tirer de toute leur force, ils ne s'amusoient qu'a faire des courbettes, respirant un air marin qui les faisoit hannir et les advertissoit que la mer estoit proche, ou l'on dit que leur Maistre se couche toutes les nuits" (Scarron 1958: 532). Scarron rejects the oft-depicted image of the dawn for one of dusk. While in Cervantes, the figures of Apollo and Aurora command attention, Scarron turns away from celestial deities and focuses on the deity's horses who are more than pleased to be descending and returning home, as they frolic in the skies. This shift alerts the reader to a lesser ambition on the part of the writer: instead of a would-be hero that sallies forth, this novel will deal with playful "low" subjects as pointed out by the horses.

Indeed, the work sets dusk as the time when some weary travelers arrive in a cart. While Cervantes failed to provide the location for his work, placing it in a town whose name he does not remember, Scarron is very specific: as the gates of storytelling open, we find ourselves in Le Mans. ${ }^{31}$ Notice the similarity with the name of the area cited by Cervantes, La Mancha. Like La Mancha, Le Mans points to the provincial. ${ }^{32}$ Thus, the gates of storytelling place the reader far from the centers of culture and power and in a lesser-known, local environment. Location then signals parody of the chivalric and heroic novels of the time, where London, Carthage and Constantinople abide side by side with faraway places that strain credibility while insisting in their reality. ${ }^{33}$

As Scarron seeks to transform the idealized into the realist, he inverts the signs of beginnings and provides instead a narrative of endings (sunset) at the inception of

\footnotetext{
31 Born in 1610, Scarron was named secretary to Charles de Beaumanoir, bishop of Le Mans, moving to the town in 1632. He remained there until 1640 when he returned to Paris. He did, however, travel to Rome in 1635 with the bishop of Le Mans as part of a secret mission to the pope led by the archbishop of Lyons (De Armas 1972: 18).

32 Bernard Beugnot (1994) asserts that "Le Roman comique is concerned less with offering a picture of provincial life than providing a devalued and ridiculous image of it to its Parisian audience" (1989: 294).

33 Ellen R. Welch discusses in details the geography of the French heroic romances. It is known, for example that Madelaine de Scudery "scrupulously researched both the histories and places in which she set her novels." Welch analyzes "the apparent contradictions between authors' documentary assertions on one hand and their seemingly superficial or overly domesticated portrayals of foreign lands and peoples" (Welch 2011: 29).
} 
his text. The second part of the novel, published in 1657 again insists on beginning at the wrong time, at night. But this time, the few poetic terms are engulfed in the realities of the moment: "Le soleil donnoit a plomb sur nos Antipodes et ne prestoit a sa soeur qu'autant de lumiere qu'il luy en fallout pur se conduire dans une nuit fort obscure" (1958: 671). While explaining that everyone slept, he makes the point that poets and lovers were awake, the first bedeviled by verses difficult to compose ("difficiles a tourner" [1958: 671]), and the second called "Ames damnées" (1958: 671). Echoing Cervantes, but in a much lighter tone, poets and lovers are associated with darkness, and perhaps with melancholy. And yet, saturnine melancholy hardly emerges from a text that often pokes fun at poets and portrays lovers in both comic and stilted fashion.

As noted, Cervantes had created a second beginning with the words Don Quixote thought his chronicler would use. Scarron begins directly with the description of dusk, which is followed by the intrusive explanation of the narrator: "Pour parler plus humainement et plus intelligiblement, il estoit entre cinq et six quand la charrette entra dans les Halles du Mans" (1958: 671). In other words, while idealized texts waste their time in obscure poetic language, Scarron emphasizes the human or the quotidian-the time of day. This is the first of many moments throughout the novel where the narrator will intrude in order to deflate his own narrative. In the first interpolated tale narrated in chapter 9, he pretends to forget the historical circumstances: "aux nopces de Philippes second, troisieme ou quatriesme, car je ne scai pas lequel" (1958: 552), while the heroic romances are forever seeking historical detail. It is not as if different narrators are present, as in Cervantes. Here, the narrator over and over interferes in his own narration to provide a perspective that somehow debases idealized moments. One last example: when Don Carlos and Princess Porcia are married, rather than emphasize the feast, the narrator intrudes to provide details that are absent in idealized works: "On dit qu'ils se leverent tard le lendemain; ce que je n'ay pas grand'peine a croire" (1958: 566-67).

But let us return to the beginnings of the novel. Once we are done with the second gate into storytelling, Scarron would satisfy the first, describing those that came in the cart. We soon find out that these are actors in a provincial troop, who do not seem to gain much from their constant travels from town to town. Even the lead actor, the main character, fails at grandeur, at least at this point: "Un jeune home, aussi pauvre d'habits que riche de mine, marchoit a costé de la charette. Il avoit un grand emplastre sur le visage, qui lui couvroit un oeil et la moitié de la joue, et portoit un grand fuzil sur son épaule, dont il avoit assassiné plusieurs Pies, Geais et Corneilles, qui luy faisoient comme une bandoulière, au bas de laquelle pendoient par les pieds, une poulle et un oyson qui avoint bien la mine d'avoir este pris a la petite guerre. Au lieu de chapeau, il n'avoit qu'un bonnet de nuit, entortille de jarretières de différentes couleurs, et cet habillement de teste estoit une manière de Turban" (1958: 532).

In many ways, the description of his clothing and the winged creatures that would feed him seek to emulate the beginnings of Cervantes' novel where the impoverished gentleman's clothing as well as the foods he consumed different days of the week, place him socially as a careworn hidalgo. Scarron creates a heuristic imitation of Cervantes' hidalgo, making him more of a paradoxical and comical figure in 
this initial description. For example, Scarron contrasts his poverty of means with his noble bearing; but at the same time uses the word "mine" or bearing to refer both to the actor and to the hen and gosling he carries. While Cervantes' gentleman will have to change into a knight, this actor, whose name is Destin (Destiny) wears some of the clothing he will need to be a player. Furthermore, when we learn that Destin is wearing a bandage over his face, we begin to associate him with the doubling of character in Cervantes. There, Don Quixote imagined himself a solar hero, while he was actually shadowed by Saturn. Here, Destin is both a handsome actor and someone who has to hide or "shadow" himself. Although acking the complex, comic and absorbing Prologue penned by Cervantes, the vestibule and the gates seem to create a strong dialogue with his predecessor.

There is one more element that actually reflects Scarron's thoughtful reading and imitation of Don Quixote. Towards the end of the first part of Cervantes' novel, the knight is imprisoned in a cart and told that he is enchanted. His captors mean well since they are taking him home to "cure" him of his madness. Don Quixote accepts the notion that he is enchanted, but does not understand why he is not taken in the usual contraptions of the chivalric novels: "encerrados en alguna parda y escura nube, o en algún carro de fuego, o ya sobre algún hipogrifo o otra bestia semejante" (2007: 483). But in the end he comes to accept the cart as the kind of vehicle used in modern times. What characterizes this cart is that it is led by "perezosos y tardíos animales" (2007: 483). More than once we are told of the slow pace of the oxen. If we pair it with the beginning of the chronicle as conceived by Don Quixote, we can come to understand its symbolic importance. Although the enchantment is but a trick in the eyes of his captors, it could well have a symbolic function in the novel, being one more of the celestial chariots imagined by the knight. Indeed, ever since classical antiquity, planetary gods were depicted as riding in chariots led by animals assigned to them. Venus, for example, is often seen in chariots led by either doves or swans, while Saturn, the furthest and slowest of planets according to Ptolemaic astrology, is portrayed as drawn by dragons or by slow and slothful oxen. Cervantes first tells in his Prologue of a writer afflicted by saturnine melancholy; secondly, he tells of Don Quixote as wanting to be a solar hero as he imagines the chariot of the sun leading him at dawn during his first sally; and third, towards the end of the novel, he pictures his knight returning home in a cart led by oxen, the beasts of Saturn (De Armas 2011: 168-72). Saturn, as the planet that grants the most secret and the highest wisdom is then the ruler of Cervantes' novel.

Scarron utilizes this astrological lore in Cervantes' novel. He begins his text as the sun sinks into the horizon, dimming his light. According to ancient astrology, Saturn was the old sun, one that had cooled off and was now a shadowed figure. In fact, Scarron brings the chariot of Saturn to the very beginnings of the novel, not only through the image of the setting sun, but also through the cart, since, like Don Quixote's, it is led by four ragged oxen: "attellée de quatre boeufs fort maigres" (1958: 532). Like Cervantes, Scarron is writing a parody of idealist fiction; but also like Cervantes he proposes that he is led, not by Apollo, but by a darker deity, Saturn. After all, illness of all kinds belong to Saturn, and a mysterious ailment like the one that gripped Scarron and turned him into what some thought was a rather monstrous figure, could well place him under the influence of this paradoxical planet that 
brings sufferings but also wisdom. If there are key failures in Scarron's novel, they do not derive from the imitation of Cervantes deepest symbols. Rather, they have to do with the failure to fashion an intriguing author figure, and to a greater degree, the inability to create a complex figure like Don Quixote.

Destin, the hero of the work, after the rather impacting first scene, becomes somewhat of a cardboard figure, mimicking heroes of idealized fiction. We sense that he is not lowborn, but that there was a child substitution at his birth; we are slowly treated to his many adventures and his love for another shadowed character, Estoile, the star of his life who has become the female lead player in the troupe to hide her noble identity and avoid an old enemy. Amidst the chaos of the novel, these and other idealized characters slowly reveal their secret past and infuse a sense of order and virtue. At the same time, the many romanesque mysteries that surround these characters substitute for the shadowed wisdom of Cervantes' fiction. The problem is that Destin seldom draws our sympathy; and he almost never brings out laughter. Perhaps his clumsy dealings with his beloved Leonore in Rome bring him closer to a reader, but his other adventures do not seem to round out his character. The comical belongs to Ragotin, a widowed lawyer who wishes to love, but cannot decide on a woman; he wishes to write, but can only steal others' fictions. This separation of the idealized and the comical frustrates the creation of a multi-dimensional character, and thus the novel is diminished when compared to Don Quixote who is in many ways the one who actualizes chivalric fiction, but points to the madness of believing in its reality. ${ }^{34}$ Destin is in no way mad, and the many delays and frustrations (as influenced by Saturn) in the love affairs, seem but a common trait in idealized fiction; while the vain and ridiculous actions of Ragotin, rarely engross the reader. ${ }^{35}$

In Cervantes, Sancho is a down to earth character, often described as being a phlegmatic. In the Roman comique, Ragotin resembles him, but lacks his folk wisdom and is simply prone to disasters, providing, as Sandrine Berrergard's asserts "une vision très terre-à-terre de la realité" (2003: 116), Roland Racevskis explains that in the Roman comique, Ragotin tends to wind up literally "down to earth," (2013: 126). He falls from a horse, trips or is pushed down, since one of his traits is "his susceptibility to gravitational force" which "increases through the course of the narration" (Scarron 2012: 126). Even though early modern astrologers and philosophers often view Saturn as the highest of planets, they also connect it to the element earth. ${ }^{36}$ Ragotin's constant falling has to do with a negative saturnine influence.

\footnotetext{
34 Discussing Sorel's Le Berger extravagant in relation to Cervantes' novel, Syrovy explains: "We are talking about the transfer of imitatio to a character, thus dodging, as it were, possible accusations of untruthfulness. As a technique of dissimulation, the fact that Lysis is 'responsible' for everything that is pastoral about Le Berger extravagant, and Don Quijote for the genuinely chivalric inhis story, works wonders" (2013: 236).

35 Ernest Simon views Ragotin as an important vehicle for parody: "the most sustained attack on the conventional novel is contained in the adventures and misadventures of the hapless little Ragotin. There can be little doubt that Ragotin, with his diminutive stature and ineffectual pugnacity, embodies a parody of the traditional hero of romance and of the conventional lover modeled after d'Urfé's Céladon" (Simon 1963: 132).

36 According to the "Lunario nuevo, perpetuo y general by Jerónimo Cortés, Saturn is "frio y seco, melancolico, terreo, masculino y diurno" (cited in Hurtado Torres 1984: 33).
} 
Perhaps Saturn's malign designs could be inversely detected in his constant noisemaking. After all, the children of Saturn "aman la soledad, y aborrecen los bullicios, y regozijos" (Hurtado Torres 1984: 34).

At the very beginning of the novel, the players dismount from their chariot, while Destin simply continues walking beside them. The narrator focuses on the latter, but briefly: Destin enters into a conversation with the sheriff's lieutenant, La Rappiniere, but this is interrupted: "par quelques coups de poing et juremens de Dieu que l'on entendit au devant de la charrette. C'estoit le valet du Tripot qui avoit battu le Charretier sans dire garre, parce que ses boeufs et sa jumment usoient trop librement d'un amas de foin qui estoit devant la porte" (1958: 533-34). As Nina Ekstein has argued, disruptive noises in the novel derive from animals, gunshots, human shouts, grunts and other sounds (1988: 38). ${ }^{37}$ Interruptions, confusions and farcical battles permeate the action as Ragotin moves about creating laughter and confusion; and as the noisy narrator asserts over and over again that what he writes is haphazard: "cependant que ses bestes mangerent, l'Auteur se reposa quelque temps et se mit a songer a ce qu'il diroit dans le second Chapitre" (2012: 7).

As the highest of the Ptolemaic planets, Saturn is suffused with silence, or at the very least with subtle conversation as exemplified in many of the exchanges between Don Quixote and Sancho. The noise of Scarron's novel is inimical to the seventh Ptolemaic planet. It stems in part from the voice of the narrator, a voice that echoes that of Scarron himself. His voice speaks against Saturn's malevolence, against the world and the body that engulf him. He will make noise, make a travesty of things, rail against the highest planet which offers him suffering but no relief through wisdom. And for all the narrator tries, he cannot make Destin, his idealized destiny into a plausible figure. Lennard J. Davis asserts that: "the very structures on which the novel rests tend to be normative, ideologically emphasizing the universal quality of the central character whose normativity encourages us to identify with him or her" (1995: 11). Scarron's main character is ironically depicted as "normal." Emerging from the heroic or chivalric romances, he is so foreign to Scarron's physical suffering and physical form, that he must remain what he is: A character without true anguish. ${ }^{38}$ Perhaps this is how we should read the Roman comique, as a work whose noise, chaos and corporality rails against the heavens and delights in confusing and scandalizing Parnassus, the place of the poets. If, as Mary Gaylord has argued: "In Cervantes' literary cosmos, the authorial deity is a crippled god" (Gaylord 1983 102), in Scarron the god is all too human, speaking out his disabilities. It may be argued that our purported indifference to Scarron is based on society's "radical repression of disability" (Davis 1995: 22). Perhaps it is also based on the author's

\footnotetext{
37 “...characters make noise, are interrupted by noise. Whether its source is human, animal, or mechanical, cacophony is everywhere" (1988: 34). For a study of theories of sound in literature see Radomil Novác (2019).

38 Destin's desperation, even when he cannot find Estoile, or even when she is kidnapped, seems more like a trope of heroic fiction than "sincere" emotions. It may be simply part of the continuous games of sentiment played at the salons of the period, where the Carte de Tendre, included in Madeleine de Scudery's Clelie, served as perfect example on how to play at the passions.
} 
inability to fashion Destin as a verisimilar suffering lover, as someone who can give a voice to pain.

The vestibule and entry in both Don Quixote and the Roman comique provide the reader a remarkably complex view of the authors and their aesthetics. They turn away from Parnassus and from idealized literary forms in order to present a new shadowy perspective on the visionary and melancholy author. Through parody, they poke fun at solar imagery and reject the solar idealized hero in order to laugh at chivalric or heroic novels and in so doing, provide an alternative, where the quotidian life of the provinces becomes infused with new meanings. While Cervantes' whimsical child continues to astound, emerging from the anguished sounds of a prison; Scarron, albeit composing a remarkable imitation of Cervantes' novel, fails to fascinate since he seems unwilling to transform the noises of a body racked with pain into complex characters that can be part of a quotidian existence and at the same time strive, in a compelling way, to rise above the noise of this world.

Open Access This article is licensed under a Creative Commons Attribution 4.0 International License, which permits use, sharing, adaptation, distribution and reproduction in any medium or format, as long as you give appropriate credit to the original author(s) and the source, provide a link to the Creative Commons licence, and indicate if changes were made. The images or other third party material in this article are included in the article's Creative Commons licence, unless indicated otherwise in a credit line to the material. If material is not included in the article's Creative Commons licence and your intended use is not permitted by statutory regulation or exceeds the permitted use, you will need to obtain permission directly from the copyright holder. To view a copy of this licence, visit http://creativecommons.org/licen ses/by/4.0/.

\section{References}

Allen, J. J. (1969). Don Quixote: Hero or fool?: A study in narrative technique. Gainesville, FL: University of Florida Press.

Avalle-Arce, J. B. (2002). Don Quijote como forma de vida. Alicante: Biblioteca Virtual Miguel de Cervantes.

Bearden, E. B. (2016). Monstrous births and crip authority: Cervantes, the Persiles, and the representation of disability. In Mercedes Alcalá-Galán, Antonio Cortijo Ocaña (Eds.) "Si ya por atrevido no sale con las manos en la cabeza”: el legado poético del Persiles cuatrocientos años después, eds., Francisco Layna Rans. eHumanista/Cervantes 5, 59-84.

Berregard, S. (2003). Les animaux dans trois oeuvres de Scarron: Jodelet ou le maître-valet, Dom Japhet d'Arménie et le Roman comique. PFSCL, 30(58), 113-130.

Beugnot, B. (1994). Cultural life outside Paris. In D. Hollier (Ed.), A new history of French literature (pp. 292-297). Cambridge: Harvard University Press.

Cadorel, R. (1960). Scarron et la nouvelle espagnole dans le "Roman Comique." Aix-en-Provence: La Pensée Universitaire.

Chardon, H. (1904). Scarron inconnu. Paris: Champion.

Close, A. (1978). The Romantic approach to Don Quixote. Cambridge: Cambridge University Press.

Conroy, P. V., Jr. (1974). The narrative stance in Scarron's roman comique. The French Review Special Issue, 6, 18-30.

Davis, L. J. (1995). Enforcing normalcy: Disability, deafness and the body. London and New York: Verso.

De Armas, F. A. (1972). Paul Scarron. New York: Twayne.

De Armas, F. A. (2006). Quixotic frescoes: Cervantes and Italian Renaissance art. Toronto: University of Toronto Press. 
De Armas, F. A. (2011). Don Quixote among the Saracens: A clash of civilizations and literary genres. Toronto: University of Toronto Press.

Cervantes, Miguel de (2007). Don Quijote de la Mancha, Francisco Rico (Ed.). Madrid: Punto de Lectura

DeJean, J. (1977). Scarron's roman comique: A comedy of the novel, a novel of comedy. Berne: Peter Lang.

Dentith, S. (2000). Parody. London: Routledge.

Ekstein, N. (1988). Noise and (in)coherence in Le Roman comique. Papers on French Seventeenth Century Literature, 15, 33-44.

Ficino, M. (1989). Three books on life, Carol V. Kaske and John R. Clark (Eds.). Binghamton NY: Medieval and Renaissance Texts and Studies.

Gaylord, M. (1983). Cervantes' portrait of an artist. Cervantes: Bulletin of the Cervantes Society of. America, 3(2), 83-102.

Genette, G. (1997). Paratexts: Thresholds of interpretation. Cambridge: Cambridge University Press.

Hogdson, R. H. (1982). The parody of traditional narrative structures in the French anti-novel from Charles Sorel to Diderot. Neophilologus, 66(3), 340-348.

Hurtado Torres, A. (1984). La astrología en la literatura del Siglo de Oro. Alicante: Instituto de Estudios Alicantinos.

Jasinski, R. (1948). Genèse et sens du Capitaine Fracasse. Revue d'Histoire littéraire de la France, 48(2), 131-156.

Klibansky, R., Panofsky, E., \& Saxl, F. (1964). Saturn and melancholy: Studies in the history of natural philosophy, religion and art. London: Thomas Nelson.

Lida de Malkiel, M. R. (1964). El amanecer mitológico en la poesía española. Revista de Filología Hispánica, 8, 77-110.

Lo Ré, A. G. (1990). A new first: An illustration of Don Quixote as 'Le capitaine de carnaval', Leipsig, 1614. Cervantes: Bulletin of the Cervantes Society of America, 10 (2), 95-100.

Margolis, H., \& Shapiro, A. (1987). Countering negative images of disability in classical literature. The English Journal, 76(3), 18-22.

Paz Gago, J. M. (1995). Semiotica del Quijote: teoría y práctica de la ficción narrativa. Amsterdam: Rodopi.

Portús, J. (2008). Envidia y conciencia creativa en el Siglo de Oro. Anales de Historia del Arte, volumen extraordinario, 135-49.

Racevskis, R. (2012). Abundance and waste in Scarron's roman comique: Early modern environments and terrocentric identity. The French Review, 86(1), 24-35.

Riley, E. C. (1956). "El alba bella que las perlas cría": Dawn-descriptions in the novels of Cervantes. Bulletin of Hispanic Studies, 33(3), 125-137.

Rodríguez, A. (1995). La conversación en el Quijote: subdiálogo, memoria y asimetría. York, SC: Spanish Literature Publications Company.

Scarron, P. (1857) Le Roman comique, ed. M. Victor Fournel. Paris: P. Jannet. https://www.gutenberg. org/files/27772/27772-h/27772-h.htm

Scarron, P. (1958) Le Roman comique. Romanciers du XVIIe siècle, ed. Antoine Adam. Paris : Gallimard,531-898.

Scarron, P. (2012). The comical romance, Jacques Houis. Ric mond (Trans.), UK Alma Classics.

Serroy, J. (1981). Roman et réalité: les histoires comiques du XVIIe siècle. Paris: Minard.

Simon, E. (1963). The function of the Spanish stories in Scarron's roman comique. Esprit createur, $3(3), 130-136$.

Stavans, I. (2015). Quixote: The novel and the world. New York and London: W. W. Norton.

Syrovy, D. (2013). Tilting at tradition: Problems of genre in the novels of Miguel De Cervantes and Charles Sorel. BrilllRodopi, Amsterdam.

Travers, M. (2001). European literature from romanticism to postmodernism: A reader in aesthetic practice. London and New York: Continuum.

Van den Doel, M. (2010). Ficino, Diacceto and Michelangelo's presentation drawings. In R. Bond, J. Maap \& T. Weststeijn (Eds.), The making of the humanities. I: Early modern Europe (pp. 107-132). Amsterdam University Press, Amsterdam.

Vélez-Sáinz, J. (2006). El Parnaso español: canon, mecenazgo y propaganda en la poesía del Siglo de Oro. Madrid: Visor Libros.

Vitoria, B, de.(1676). Primera parte del teatro de los dioses de la gentilidad. Imprenta Real, Madrid 
Welch, E. R. (2011). A taste for the foreign: Worldly knowledge and literary pleasure in early modern French fiction. Newark: University of Delaware Press.

Worden, W. (2019). Don Poliondo, Don Quixote and Cervantes' transformation of the knight errant to an erring knight. Laberinto Journal, 12, 29-49.

Publisher's Note Springer Nature remains neutral with regard to jurisdictional claims in published maps and institutional affiliations. 